\title{
Las Negociaciones en un mundo globalizado
}

\author{
Prof. Fernando GUTIÉRREZ RODRÍGUEZ
}

"El término Negociaciones a nivel Internacional refleja una búsqueda constante por entender y comprender un proceso muy dinámico y abierto, que persigue obtener mejores acuerdos a niveles comerciales y económicos con empresas y empresarios de distintas nacionalidades $y$, a su vez, enriquecer y fortalecer nuestras relaciones con ellos de manera duradera y permanente sin afectar o poner en riesgo nuestros propios intereses"

En una sociedad globalizada, marcada por el grado de adaptación de las empresas y las personas por ser cada vez más competitivos (en la asimilación de la información y el conocimiento, reducción de costos, precios competitivos, mejores productos, y procesos, etc.) se hace necesario conocer el concepto del término "negociaciones" a nivel internacional y la importancia dentro del contexto del mismo en los negocios en sí.

Ahora bien, ¿qué significa negociación? y ¿en qué se diferencia este término si nos referimos al ámbito "internacional”?, es decir: ¿es diferente negociar a nivel internacional, que a nivel local?. Para empezar, comenzaremos explicando que la negociación es un proceso permanente, y común a todas las personas ya que todos, absolutamente todos negociamos en distintos escenarios, vale decir, involucra a dos o más partes, claramente diferenciados en su función y rol, que tienen, sin embargo, intereses distintos, pero que buscan una solución o acuerdo en común. Es decir, si soy un vendedor (hablando en términos estrictamente de negocios), buscaré el "mejor (o mayor) precio" para mi producto o servicio; distinta será mi posición si soy comprador, pues buscaré y trataré de "regatear" y pagar el precio más bajo posible por el bien en negociación.

A partir del concepto de proceso de negociación, y de la clara identificación de los intereses de ambas partes, los negociantes tratarán, en consecuencia, de desarrollar una serie de técnicas y estrategias para tratar de encontrar alternativas mutuas de solución a través de propuestas conjuntas, mejorar la 
comunicación existente entre las partes, de manera tal que se encuentre una posición en común que beneficie a ambos y principalmente, se fortalezca la relación entre los actores que seguramente desearán volver a hacer negocios entre sí, o buscar experiencias similares en un futuro no muy lejano. Enrique Cornejo, en su libro Negociaciones de calidad afirma lo siguiente: "En nuestra opinión, hablar de ciencia de la negociación no es una afirmación valedera en sentido estricto, pues para que haya ciencia debe existir un objeto propio de estudio y también un método de estudio...lo que hay son estrategias, técnicas, sistematización, y casos, pero no exactamente ciencia".

Diremos entonces, que el uso y concepto de negociación ( 2 "otrora objeto de estudio casi exclusivo del mundo diplomático y las relaciones internacionales") aplicado a los negocios internacionales se hace cada vez necesario en el estudio de las ciencias empresariales, ya que sin una eficiente negociación entre las partes, simplemente se cierra toda posibilidad de acuerdo comercial a futuro y lo que es peor, se frustra cualquier posible alternativa de expandir a futuro nuestros productos en mercados externos, y por consiguiente echar a perder toda una fuente de oportunidades, líneas de financiamiento, e ingresos económicos en organizaciones que pasan de una visión "etnocéntrica" de los negocios (encerrado en los mercados internos) a una visión "Policéntrica" (abierta a ingresar e incursionar en mercados internacionales, considerando a cada uno de ellos como único en particular).

El negociar a nivel internacional, sin embargo, encierra un grado mayor de complejidad, ya que implica no solo conocer el "intorno" o condiciones propias de la negociación de compra - venta, sino principalmente un entorno complejo y muchas veces difícil de asimilar. Es así, que al hablar de negociaciones internacionales tendremos que hacer un planeamiento previo del mercado en el cual nos interesa negociar (de acuerdo al producto o servicio a ofrecer) y analizar detalladamente:

1) Macro entorno: determinado principalmente por:

- Factores Políticos - Legales: niveles y estructuras arancelarias, medidas paraarancelarias (tales como cuotas, subsidios, licencias, medidas antidumping, y regulaciones gubernamentales), análisis de la política de comercio exterior impuesta por cada gobiernos extranjero, así como el nivel de injerencia de estos mismos gobiernos en las actividades

1 Negociaciones de Calidad. Teoría y Casos: Enrique Cornejo Ramírez. Fecha de Publicación: noviembre 2012.

2 Negociaciones Comerciales Internacionales: Texto y Casos. Anibal Sierralta Ríos. Fecha de Publicación: julio 2005.

3 Término acuñado por Fernando D'Alessio Ipinza. Texto El Proceso Estratégico. Un enfoque de gerencia. Fecha de Publicación: enero 2013. 
empresariales, las instituciones tutelares de los Estados, y el respeto a la propiedad privada (sobre todo extranjera).

- Factores Económicos: nivel de ingreso de las personas en promedio, el crecimiento de las principales actividades económicas, la tasa de inflación vigente, tipos de cambio a nivel histórico.

- $\quad$ Factores culturales: idioma, religión, costumbres, tradiciones, instituciones sociales representativas, entre otras.

- $\quad$ Factores comerciales: acuerdos y tratados internacionales vigentes, principales competidores en dichos mercados, precios existentes, márgenes comerciales de acuerdo al mercado.

2) Micro entorno: entre otros, precios, las condiciones de entrega, líneas de financiamiento, pago de pólizas (seguro) y flete (transporte), descuentos por volumen negociado, lugar de entrega de la mercadería, etc.

Ahora bien, el análisis previo o el interés por uno o más mercados en particular suponen un marco previo fundamental al proceso de la negociación en sí, que influenciarán sin duda en el desarrollo de un plan o MAAN (mejor alternativa a un acuerdo negociado) a tratar durante la etapa posterior en la negociación propiamente dicha, vale decir en la conversación que sostendrán un vendedor a nivel internacional y un comprador. Por lo tanto, previo a la negociación tendré que analizar si un mercado es atractivo o nó (hablando en términos económicos), deberé encontrar la forma correcta de poder entablar una comunicación inicial con un comprador potencial y mostrarle mi propuesta comercial (¿lo haré vía e-mail?, ¿será exclusivamente a través del Chat? ¿Me será más conveniente participar en misiones y ferias comerciales? ¿Buscaré un intermediario comercial?, y posteriormente analizaré el grado de dificultad para acceder a los mercados de mi interés basado en cuestiones no económicas pero fundamentales como el aspecto cultural o idiosincrasia de un negociador en particular. Por ejemplo ¿utilizaré el mismo estilo y énfasis al hablar de precios, negociando con los norteamericanos, que con los japoneses? ¿Cuál deberá ser el lugar adecuado para negociar con empresarios chinos? O ¿deberé llevar presentes (regalos) a negociadores no muy frecuentes como los árabes?

El conocer con quién se va a negociar es fundamental para desarrollar a partir de ahí las mejores estrategias y técnicas orientadas al cierre exitoso en una negociación ya que cada negociación es única y no se admite un MAAN para varias negociaciones a la vez. Igualmente, al momento de negociar debemos de estar muy consciente del nivel máximo de concesiones (punto de equilibrio) que estaré dispuesto a otorgar a la otra parte, teniendo en cuenta que no estaré 
dispuesto a sacrificar mis intereses negociando por debajo del precio mínimo, al cual estaré dispuesto a ofrecer mi bien o producto según el mercado en el cual estoy negociando.

Por ultimo, la negociación a nivel internacional debe ser vista como un proceso constante y abierto para dar un mayor valor agregado a mi empresa, y no como una lucha de poderes, un tire y afloje permanente entre negociantes de distintas nacionalidades, ni mucho menos como una "inmolación" o "sacrificio" en favor de empresarios de otras naciones; por el contrario, negociar internacionalmente es una posibilidad única de enriquecer mis relaciones comerciales y contractuales con empresarios de diferentes países en los cuales me interesa ingresar, preveer todos los escenarios posibles en los cuales puedo y debo desarrollar habilidades, y prepararme para lograr acuerdos favorables a mi organización

\section{Bibliografía}

1. Negociaciones de Calidad. Teoría y Casos: Enrique Cornejo Ramírez

2. Negociaciones Comerciales Internacionales: Texto y Casos. Anibal Sierralta Ríos.

3. Negociaciones Eficaces. Pinkas Flint 